\title{
Human Capital, Skills, and Uneven Intraurban Employment Growth: The Case of Göteborg, Sweden, 1990-2008
}

\author{
Jonathan Borggren and Rikard H. Eriksson \\ Department of Geography and Economic History, Umeå University, 90187 Umeå, Sweden \\ Correspondence should be addressed to Jonathan Borggren; jonathan.borggren@geography.umu.se
}

Received 5 November 2013; Revised 17 January 2014; Accepted 20 January 2014; Published 12 March 2014

Academic Editor: David Wong

Copyright (c) 2014 J. Borggren and R. H. Eriksson. This is an open access article distributed under the Creative Commons Attribution License, which permits unrestricted use, distribution, and reproduction in any medium, provided the original work is properly cited.

\begin{abstract}
Recent research has elucidated the role of talents to explain urban growth differences but it remains to be shown whether urban dynamics, such as human capital and a mixed local population, can be linked to intraurban employment growth. By use of a unique longitudinal database, we track the economic development through the lens of intraurban employment growth of a number of primary urban areas (PUA) in Göteborg, Sweden. Regarding factors influencing employment growth, we find that relative concentrations of human capital protect areas from rising unemployment during severe recession (1990-1993) and recovery (19902000) while the composition of skills is beneficial during recovery (1990-2000) and long-term growth (1990-2008). Our findings suggest that neither too high concentrations of creative occupations nor too low ones are beneficial. Thus, human capital drives much of the employment changes in relation to the recession and early transition from manufacturing to service but composition of skills is more relevant for explaining long-term intraurban employment growth.
\end{abstract}

\section{Background}

The gradual shift from manufacturing to a postindustrial knowledge-based economy has resulted in a number of events that have changed future prerequisites for economic development. These events include a deepened spatial division of labour at both regional [1] and urban [2] levels, urban decline and revitalization [3], and a growing service industry $[4,5]$. In relation to this, increasing attention has been directed towards how the changing geography of talent shapes the preconditions for regional and urban development. In particular, focus has been on the role of high concentrations of human capital and creativity when it comes to explaining postindustrial location tendencies and why certain localities prosper while others do not [68]. However, recent contributions have shown that it is not the pure agglomeration of certain industries and skills that primarily drive development but rather the composition of knowledge at both the level of the region [9-12] and within the firm [13]. Framing the issue of the geography of talents is its impact on the economic structure of the city region as a whole. In agreement with Törnqvist [14], Hutton [15] and Hansen, and Winther [2], we argue that studying the city region from a holistic perspective is not fruitful if one wishes to put the spatial division of talents in the context of contemporary urban development, especially if one wishes to understand current urban economic activity. Thus, instead of conceptualising the city as a homogenous fabric of inputs and outputs in order to compare its economic activities with other cities, most notably illustrated in the phrase of "cauldrons of creativity" [8], Hansen and Winther [2] argue that the growing complexity of location dynamics within the city needs to be highlighted and consequently also studied through intraurban analysis.

The aim of this paper is to address how the composition of urban talent and the evolving landscape of skills are related to the dynamics of intraurban employment. By connecting to the ongoing discussion on the characteristics of the urban drivers of economic development $[6,8]$, we construct two different indicators. First, an indicator of intraurban concentrations of human capitalin 84 primary urban city areas (PUA) in the metropolitan region of Göteborg (we 
use the Swedish name Göteborg throughout, instead of the English name Gothenburg), Sweden, capturing views building on human capital theory $[16,17]$. Second, an indicator of the intraurban composition of skills, reflecting relative concentrations of individuals with creative educations (here termed core) and noncreative educations (here termed comparison group), intended to reflect variety and diversity associated with Florida's ideas on the importance of a creative capital [8] and Jacobs externalities [18], emphasizing urban diversity. This is made possible by means of employee-employer matched longitudinal microdata linking attributes of individuals to features of plants and localities with a high geographical resolution that makes it possible to assess intraurban employment dynamics. The indicator is set to reflect areas with high (low) relative concentrations of core (i.e., creative skills) in comparison to the Göteborg metropolitan area. By also addressing how the composition of skills influences intraurban employment growth over time (1990-1993, 1990-2000, and 1990-2008), this paper contributes to existing knowledge in several key regards. First, we will be able to provide new insights on the role of creativity for understanding employment growth in relation to the demise of the Fordist production system and the rise of postindustrial production modes. This is done by analysing not only the relative concentration of human capital across urban areas but also the composition of skills within a city region. Second, by using one start year (1990) and three different end years, we will address how this initial composition of skills influences employment growth over different stages in the economic cycle to understand whether past activities leave traces for future development: deep recession (1990-1993), a period of recovery (1990-2000), and over a longer period of growth (1990-2008). Aligning with the literature on related variety (e.g., [9]) and diversity [18], we expect that areas with very high concentrations of certain skills (creative, that is, core or noncreative, that is, comparison group) will enjoy less significant spillover effects than areas with a mixed population consisting of both creative and noncreative skills. Third, using an intraurban perspective on economic growth will most likely provide further evidence for the rise of uneven geographies in city regions and its relation to growing knowledge intensive business services (KIBS).

The remainder of this paper is thus embedded in the literature on talents and urban growth. This is because intensified competition through place-marketing over talents played out between cities and regions can be linked to the increasingly globalized world economy and to a structural transformation throughout many of the advanced capitalist nations during the latest decades $[2,19-22]$. To further strengthen the notion of competition, it has been shown that it may not be sufficient for a region or a city to solely rely on the existing human capital found in close proximity to the local university or research facilities, but that in-migration of human capital is needed in order to boost productivity and economic activity [23, 24]. From a regional perspective, attracting human capital may generate knowledge spillovers and strengthen regional competitiveness by stimulating growth, productivity, and innovation [18, 25-29]. Specifically, Jacobs [18] argued that local and regional economic diversity facilitates interactions, the so-called Jacob's externalities, between individuals with different knowledge, resulted in more innovation and better economic performance. The idea here is that people with different backgrounds, perspectives, and ideas put in close proximity to each other, preferably in a city, would benefit from exchanges of knowledge and generate businesses and industry growth as well as wage increases and growing labour force participation [30].

However, recent evolutionary contributions stress that the idea of conceptualizing Jacob's externalities as diversity or mass per se is not providing a true picture of these externalities. As Frenken et al. [9] demonstrate on Dutch regions, different types of agglomerations promote different types of externalities. While high specialization (of industries or skills) tends to induce spillovers leading to incremental innovations and thereby promoting regional productivity growth, very diverse economies, akin to the portfolio theory, are more likely to be resistant to asymmetrical external shocks and therefore show lower unemployment rates and prevent it from losing its economic mass. Instead it is related variety (not too similar or too different activities or skills) that drives the economic growth since such spillovers are not too different to be integrated but still not too similar to actually add something new. A number of empirical studies have found that it is the composition of activities in a region (not mass or specialization or diversification as such) that spurs economic development and in particular employment growth, at both regional level [9, 10] and firm level [13, 31]. Thus, the composition of industries and skills seems to be of more importance than (the lack of) mass per se. In relation to this, the ability of firms and industries to withstand external shocks and gradual changes is closely related to the concept of resilience $[32,33]$ where a system is considered in equilibrium prior to a shock. In relation to the bust-and-boom periods affecting the national and global economy between 1990 and 2008, the notion of equilibrium and resilience is relevant as this paper is concerned with issues of change and reactions to change. In order to avoid being labelled as a "fuzzy concept" [34], Pendall et al. [32] suggest studying the nature of the challenge or shock, the scale and speed of the shock (localglobal), and the point in time when it occurs when addressing resilience in an economic context. In this paper, we will focus on how the composition of skills influence employment growth at the intraurban level, which also can be described as the ability of firms and industries to cope with rapid changes similar to the shocks described by Pendall et al. [32].

Extending these theoretical mechanisms to the intraurban level, some clarifications may be needed as to why spillovers may occur between city districts as well as between regions and firms resulting in uneven employment growth. Assuming that workers may commute within the metropolitan area, we can also assume that knowledge may be easily transferred within the urban space, and hence opening up for the possibility of intraurban spillovers on the same basis as for intrafirm and intraregional spillovers. However, it should also be noted that intraurban spillovers may be highly dependent on specific urban circumstances, for example, the density of the city population, and on the spatial location of 
similar or related work places. Given a sizeable city district at the intraurban level with a substantial concentration of a range of different work places, spillovers may occur in accordance with the benefits granted from size and density [35] especially if the city district is isolated to a certain extent. The Göteborg metropolitan area is large enough to accommodate city districts corresponding to the above, perhaps most notably at the redeveloped waterfront [36], while also not large enough to generate substantial congestion which in turn offsets, for example, urbanization economies [11]. Furthermore, intraurban spillovers are dependent on the size and shape of the spatial area, be it a smaller city district or a larger region. Thus, the composition of the studied area contributes to how spillover is manifested where size decides whether spillovers are revealed or hidden.

The proximity between actors within the same metropolitan area then needs to be considered on the background of the increasingly uneven distribution of talent and business services recently observed in, for example, Copenhagen [2]. It is underneath the regional aggregate that processes of location dynamics take place affecting intraurban employment growth. Furthermore, the "cognitive proximity" [37] required in order to facilitate related variety, that is, the appropriate distance between two actors needed to generate innovative advances through related expertise, jargon, skills, education, and so forth, may indeed be easily addressed through frequent face-to-face interactions [38]. These interactions are most likely to occur in the close geographical proximity that characterizes the densely populated and frequented core of the Göteborg metropolitan area housing 65\% of the regions work places and businesses [39]. Building on these arguments, it is therefore reasonable to state that attracting working and residing talents through place marketing and awareness of different preferences has become essential in city and firm survival strategy [40] and can be seen through the lens of changes in urban governance from provision of necessities to explorations into new ways of generating economic growth [41]. It then becomes logical to study whether a concentration of these talents, for example, skilled and educated workers in specific sectors, has had any impact on the local economy from a longitudinal perspective.

\section{The Case of Göteborg, Sweden}

Göteborg has a profound impact on the national economy in a number of important fields. The city region has, for example, $20 \%$ of national industry employment compared to $8 \%$ of national population, the highest share of foreign exports in 2011, the biggest port in Scandinavia, and a local labour market of approximately 700000 people [42]. Many of the largest firms in the area are heavily export oriented, placing the city in a globalized context. Göteborg shares several development patterns with large and medium-sized European cities including urban renewal, gentrification, and place marketing. Perhaps the most profound result of the structural change in Göteborg has been the rise of the waterfront Norra Älvstranden $[36,43]$ containing both residences and hightech work places, reflecting how global economic events can have sustaining effects on a local level [44]. However, despite sharing several global development patterns, there are a number of specific conditions concerning local and regional planning that need to be addressed before we can commence with the analysis. For example, local regulations directly affect the direction and location of growth which to a large extent will determine the establishments of new residential and commercial property. This is implemented through written plans stating where, when, and what type of economic activities that may be located in specific urban areas. Typically, the city will purchase either vacant downtown properties or neighbouring peripheral properties in order to grow both through increased density and through expanding the urban area outwards $[45,46]$.

The economic recession of the early 1990s in Sweden included the exit of Keynesian welfare politics and the entry of liberal market reforms in a number of areas such as pensions, education, railway, and housing, which had previously been publicly owned and operated. However, the socioeconomic reforms were not as far reaching as in the UK: therefore, Harvey, based on that note, finds that the contemporary economic state of Sweden can be described as "circumscribed neoliberalization" (2005:115). Hedin et al. [47] show that market forces has been given ample room on especially the housing market in Sweden following the economic boom periods of 1986 to 1991 and 1996 to 2001 and the bust period of 1991 to 1996. The expansion of the Swedish system of higher education initiated in 1977 began to gain momentum in 1987 and resulted in a substantial growth in student enrolment throughout the 1990s [48]. Hence, growth in the human capital stock took place in parallel with the bust period of 1991 to 1996 and the layoffs in both manufacturing and services. Population growth in Göteborg was at a halt in the early 1990s and the rise in employed population gained momentum in 1997 after approximately 4 years of unemployment growth [21]. In Sweden as a whole, unemployment rose by over 300000 between 1991 and 1993 [49].

\section{Explaining Intraurban Employment Growth}

The main objective of this paper is to explore the evolving geographies of intraurban employment in relation to preexisting setups of skills and industries. We thereby use a similar model as in many previous studies assuming an underlying production function containing a single labour input due to the lack of data on capital (e.g., $[6,50])$. To do this we use individual employment data (i.e., workplaces and not place of residence) based on matched employee-employer data obtained from Statistics Sweden. Due to the high resolution and the registered workplaces of every professionally active individual, it is possible to fully analyse all employment changes in Göteborg between 1990 and 2008.

Our main spatial level of analysis is primary urban areas (PUA) (see Figure 1), which can be described as intraurban divisions of the city based on a number of attributes such as primary function, infrastructure, traffic, and provision of city service. The precincts of the PUA are to some extent also drawn based on the existence of physical obstacles [51]. 


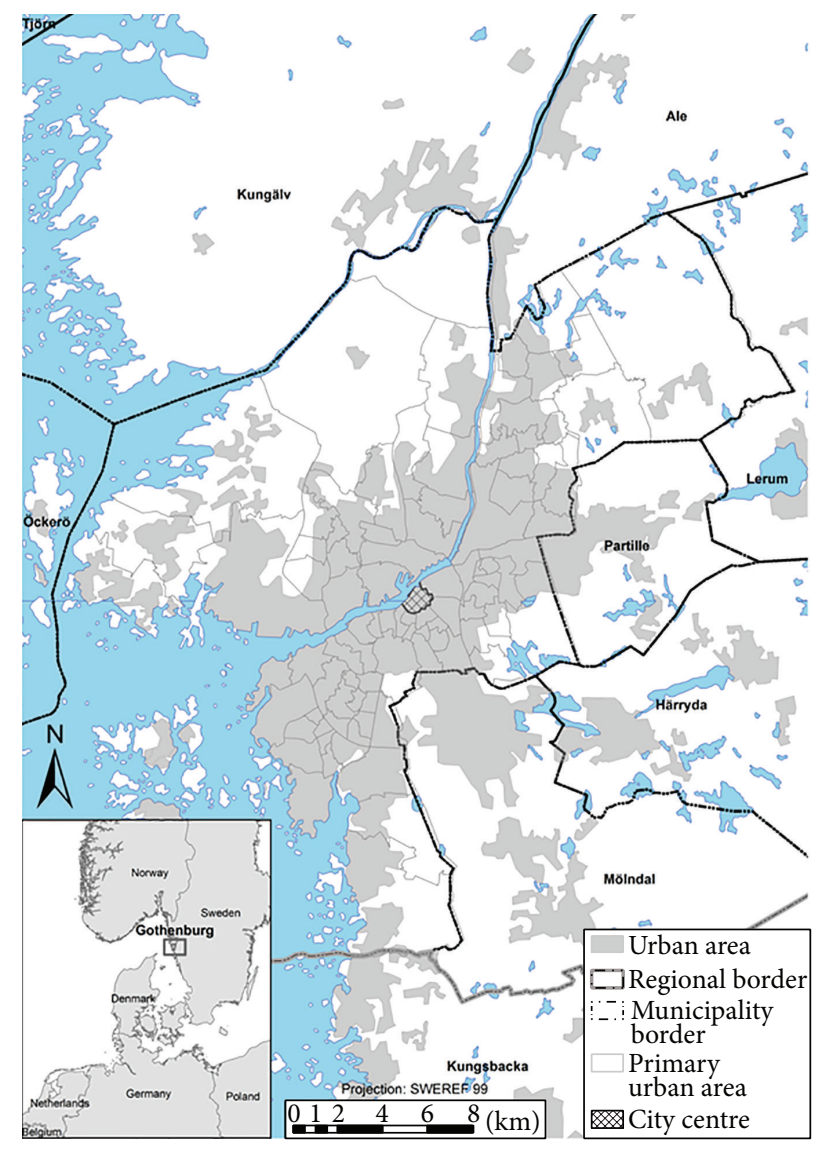

FIGURE 1: Göteborg with primary urban areas (PUA) and city centre.

They are however not administrative units and have no public responsibilities as they have no control or access to the city budget which are controlled on a higher aggregated intraurban level. Following Openshaw [52], discussing potential implications of the modifiable areal unit problem, the larger city districts are to a greater extent subject to what Openshaw would term arbitrary zoning in line with changing local and regional policies. For example, the latest city district revision in Göteborg was implemented in January 2011 halving the number of areas from 21 to 10 , which was motivated with the need to establish areal units with a critical mass of 50000 inhabitants and therefore was able to better carry the costs of the public sector [53]. In 1990, there was 94 primary urban areas in Göteborg and they are, despite the fact that they are not budgetary or politically operated, closely linked to the local context through their identity and have an average population size (approximately 5000) equivalent to recent studies on, for example, neighbourhood income effects in Sweden (e.g. [54]). The PUA were subject to minor changes on an intra-PUA level in 2001 and 2005. These changes primarily involved dissolving and removing the smaller base areas that constitute the building blocks of the PUA [55]. In the final analysis, we had to omit 10 out of 94 PUA since they were lacking a critical mass of 200 employees, resulting in a total of 84 areas.

The dependent variable used in this paper is employment change, defined as the percentage change in employment between 1990 and 1993, 1990 and 2000, and 1990 and 2008, respectively (due to a skewed distribution, these indicators were logged in subsequent regressions). Thus, we will be able to test for whether (and how) initial levels of human capital and/or composition of skills (core and comparison group) is related to intraurban employment during recession and during both short- and long-term growths which allows us to assess how the past structures influence the future courses of intraurban development. It should however be noted that intraurban performance per se is not assessed here since that would require total factor productivity and not only labour. However, as noted by Bishop [56], this approach is still able to yield testable models that explain employment growth. Employment change (Figure 2) in Göteborg mirrors the large-scale economic developments taking place in Sweden between 1990 and 2008. Hence, employment change between 1990 and 1993 in Göteborg, when the national fiscal crisis starting in 1991 had gained momentum and reached all sectors of the public and private economy in 1993, is predominantly negative in most of the PUA. As we progress towards 2000 and 2008, keeping 1990 as comparison, the number of PUA with positive employment growth increases. Arendal, an industrial PUA dominated by automotive industry, logistics, petrochemicals, and shipping and the biggest employer in the western part of Göteborg, has a major increase in employment during the two later phases. In comparison, the mostly white-collar employment in the city centre is in major decline initially (90-93), increasing marginally in the midperiod (90-00) and again increasing marginally in the final phase (90-08). This is somewhat a similar development, decreasing gradually turning into a major increase, as seen on the redeveloped waterfront north of the city centre.

3.1. Human Capital and Skill Composition. The two main indicators that we wish to assess and their relation with employment growth are human capital and composition of skills. By using both indicators, we wish to address both the evolving landscape of urban talent, operationalized as a segment of skilled workers, and the more traditional wider base of human capital. Human capital is defined as the share of employees with at least a bachelor's degree and is motivated based on a number of studies showing that concentration of human capital is crucial to understand urban and regional development since it both produces significant spillover effects and triggers the further concentration of such skills (e.g., $[6,27])$. However, this has mainly been addressed at the urban level and rarely studied in relation to employment growth at the intraurban level. Given the findings by Hansen and Winther [2] on the spatial evolution of creative jobs in Copenhagen, it is however reasonable to expect that studying intraurban development will uncover important aspects of the growth of new service jobs in relation to the relative demise of the Fordist accumulation regime and to understand the polycentricity of cities $[57,58]$.

Our second main indicator is the intraurban composition of skills in each PUA, respectively. To derive this, we use educational data, namely, highest completed education, for the 1990 Göteborg population aged 20-65 along with the 

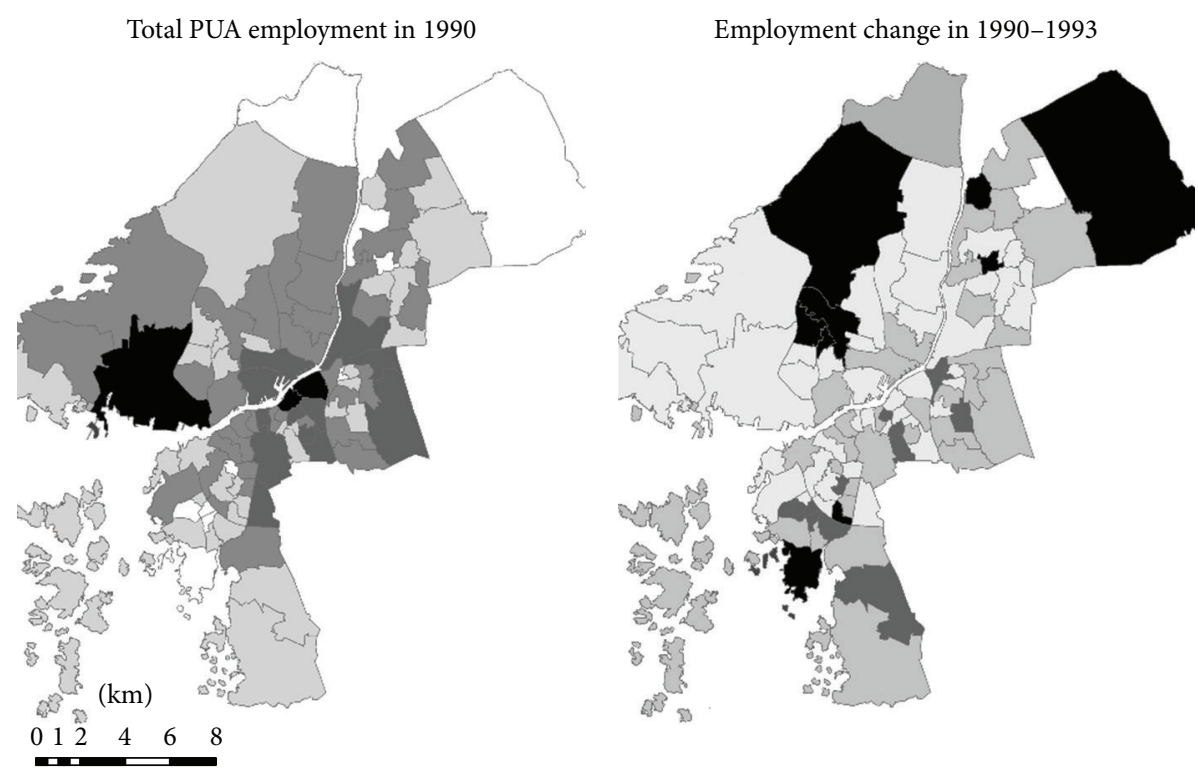

Employment

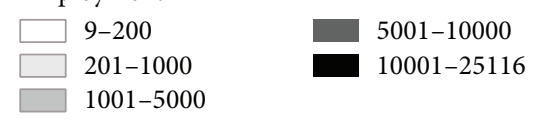

(a)

Employment change in 1990-2000

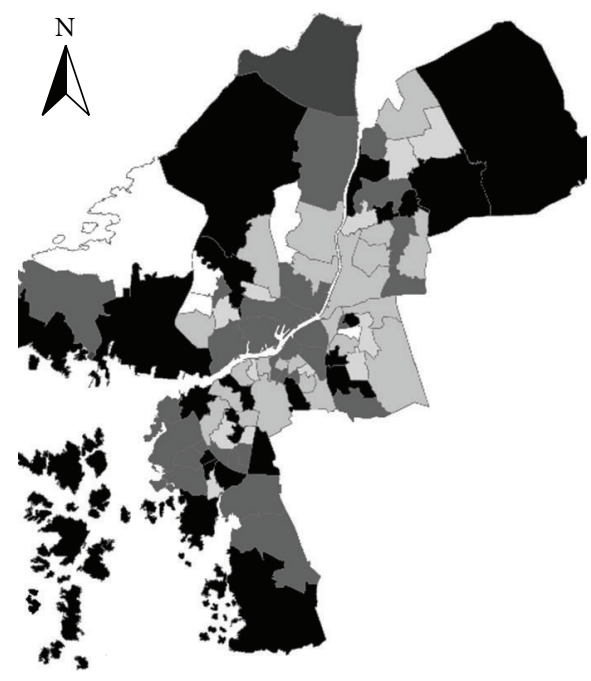

Change in 90-93

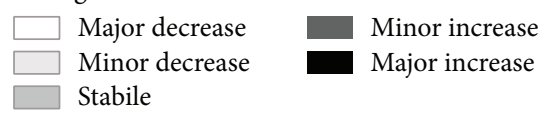

(b)

Employment change in 1990-2008

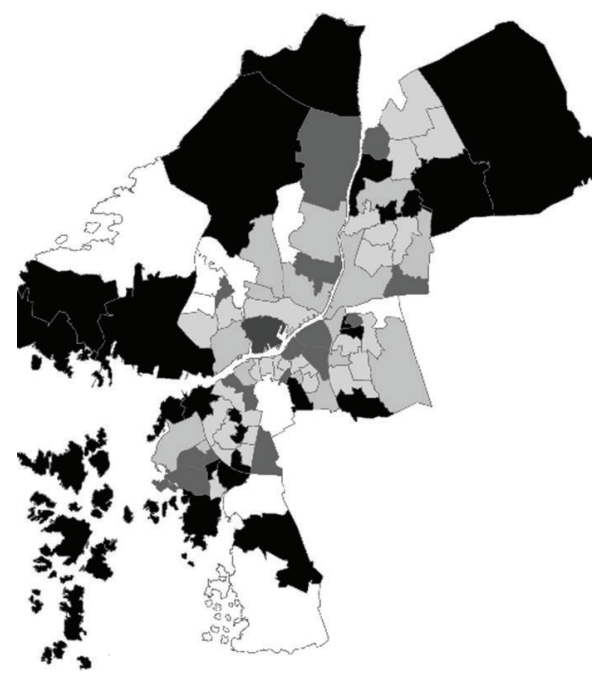

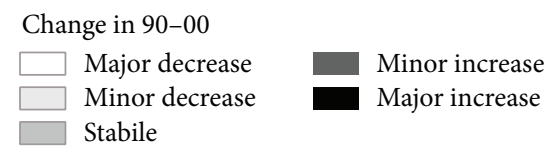

(c)

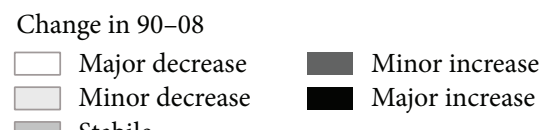

(d)

FIGURE 2: Employment in 1990 and employment change in Göteborg's PUA in 1993, 2000, and 2008. Note: major decline 50\% or more, minor decline $49-11 \%$, stabile $10 \%$ decline- $10 \%$ increase, and so forth. 
comparison group and core. Initially, we discussed using occupational data as indicator of composition; however, this would unfavourably affect the consistency of the methods used for data collection. Occupational data was collected individually using mandatory forms in 1990 as part of the national census of that year [59]. Following a change in government in 1991 future censuses were cancelled and data collection methods changed to register-based statistics. For example, a worker was initially asked to state his/her occupation in the mandatory census of 1990. After the cancellation of the censuses it became the responsibility of the worker's employer to state the occupation of said worker and to report it to Statistics Sweden. Using educational data instead (collected using national registers throughout the studied time period) will allow for a more consistently reported indicator. Furthermore, we also argue that a relatively smaller share of well-educated workers in 1990 would still be able to shape urban patterns in 2008 . We define core as individuals with an education which can be related to a rather broad definition of the "creative class" (Table 5 contains a list of selected educations comprising core). Consequently, the comparison group is defined as the rest of the population corresponding to the same age criterion. The creative educations include health-care specialists, journalists, designers, engineers, and teachers. And while it is not certain that they are professionally active in their respective education later on in life, that is, working with what they were once trained to do, a recent Swedish study [60] has observed the likelihood of education and future employment, concluding that all of the education has a minimum 50\% (humanities) future job match, that is, the likelihood of working in a field related to the specific education, and some educations have a 95\% future job match (medical school). To summarize one might argue that we use two different indicators of the competitiveness of the city that both contribute, but in separate ways, to our understanding of the importance of skills and of human capital on employment growth. While human capital captures the broader definition of skills (everyone with a bachelor's degree), core captures workers with skills that according to for example, Florida [8] are identified as imperative to generate urban growth.

To estimate the composition of skills we use the variable SkillComp defined as the location quotient of core compared to the comparison group in each area compared to the composition of workers in the entire metropolitan region. Thus, PUA scoring 1 on this indicator have a similar setup of skills as Göteborg on average, that is, a similar distribution of core and comparison group, while areas scoring high (low) have relatively greater share of creative (noncreative) skills. In order to group the PUA in a local economic context we borrow the definitions of Jones Lang La Salle [61], focusing on economic activity and function of each district as well as identifying the central business district (CBD). As can be seen from Table 1, core and comparison group employment growth during the studied time periods varies greatly depending on where in Göteborg the PUA are located and how large the share of core and comparison group is in each location.

The general patterns of economic up- and downswings are not as easily identifiable in Table 1 as one might expect.
The change in employment is without exceptions negative for comparison group between 1990 and 1993, while core more surprisingly is growing in 5 out of 8 districts despite the economic recession occurring simultaneously. Following core, we can then discern a gradual positive trend as we progress towards 2000 and 2008. Comparison group shows signs of decreasing in certain parts of Göteborg in 2008 which is surprising given the general occupational growth corresponding to the time period. It is apparent that there is an uneven geographical growth of employment in Göteborg. The waterfront district of Norra Älvstranden [36], gradually transformed from dockyards to sites of knowledge intense business services and upscale residential areas, has the biggest relative growth in core employment between 1990 and 2008.

Furthermore, we expect that the relationship between creative and noncreative skills is nonlinear, meaning that a too high concentration of either creative skills or "noncreative" skills will not produce significant spillover effects. As noted by Jacobs [18], the greater the variety in divisions of labour and skills among firms in, for example, an urban economic area the greater the ability of the said economy to attract more goods and services and grow further. Based on the benefits of a mixed local economy on the service industry [56], we study PUA that can be assumed in possession of the necessary tools for economic growth as they include both residences and work places. In addition, an unevenly distributed population poses several threats to the city/region. For example, firms tapping on the knowledge pool in an urban economic area stand a better chance of finding residents/workers with both related and unrelated skills due to the greater educational variety of the population. Thus, to capture these ideas we also include the quadratic term of SkillComp to assess whether it is the relative concentration of skills that generates spillovers and triggers employment or whether it is a certain mix of skills that is the most beneficial.

Apart from human capital spillovers, a number of other factors that may influence employment growth (such as specialization, competition, and mass) are added as controllers (e.g., [56]). First, it is reasonable to expect that the location of employment is based on previous economic activities. For example, the growth of more knowledge intensive activities tend to grow endogenously due to agglomeration economies $[6,27]$ but it may also be the case that growing sectors are located in old industrial areas where declining industries may imply new opportunities for office space [15]. Thus, four different location quotients capturing intraurban specialization of various economic activities compared to the whole metropolitan region in 1990 are constructed. These are set to reflect relative concentrations of plants in knowledge intensive manufacturing (NACE: 22, 24, and 29-35), labour intensive manufacturing (NACE: 15-21, 25, 26, 28, 36, 37), business related services (NACE: 65-67, 72, and 74), and labour intensive services (NACE: 45, 50-52, 55, 90, 93, and 95). All these categories are defined by the Swedish Business Development Agency (NUTEK, 2000) based on the similarity of inputs (like skills) and outputs of each sector. Since the two indicators on human capital (concentration and composition) capture the potential for individual-specific 
TABLE 1: Core and comparison group shares in Göteborg locations in 1990 and employment change in 1993, 2000 , and 2008.

\begin{tabular}{|c|c|c|c|c|c|c|c|c|}
\hline \multirow{2}{*}{ District (number of PUA:s), function } & \multirow{2}{*}{$\begin{array}{c}\text { Core } 90 \\
\text { Share }(\%)\end{array}$} & \multirow{2}{*}{$\begin{array}{l}\text { Comp } 90 \\
\text { Share (\%) }\end{array}$} & \multicolumn{2}{|c|}{ Change in $90-93(\%)$} & \multicolumn{2}{|c|}{ Change in $90-00(\%)$} & \multicolumn{2}{|c|}{ Change in $90-08(\%)$} \\
\hline & & & Core & $\operatorname{Comp}$ & Core & Comp & Core & Comp \\
\hline CBD (3), business, and commercial & 14,2 & 14,8 & $-7,4$ & $-12,2$ & 42,0 & 1,2 & 53,8 & $-13,8$ \\
\hline Inner city (16), residence/business & 32,4 & 27,7 & 1,4 & $-10,1$ & 33,0 & $-1,2$ & 36,3 & $-4,8$ \\
\hline East Göteborg (12), residence & 8,0 & 9,7 & 17,7 & $-5,7$ & 45,9 & $-0,4$ & 26,0 & $-25,1$ \\
\hline West Göteborg (18), residence & 5,4 & 5,3 & $-3,5$ & $-12,1$ & 32,3 & 23,0 & 43,6 & 4,1 \\
\hline North Göteborg (20), residence & 11,0 & 12,7 & $-8,9$ & $-14,6$ & $-0,6$ & $-3,9$ & 1,2 & $-16,8$ \\
\hline Industrial areas (6), industry & 13,6 & 16,0 & 16,1 & $-10,8$ & 61,7 & 26,5 & 70,9 & 22,3 \\
\hline Norra Älvstranden (3), industry & 8,8 & 8,0 & 0,8 & $-12,1$ & 43,9 & 14,1 & 79,1 & $-2,6$ \\
\hline Outer ring (16), sparse residence & 6,6 & 5,8 & 2,9 & $-2,3$ & 38,3 & 31,8 & 40,3 & 42,9 \\
\hline \multirow{2}{*}{ Sum (94) } & 100 & 100 & & & & & & \\
\hline & 55935 & 187827 & & & & & & \\
\hline
\end{tabular}

spillovers, these indicators are set to also capture plantspecific spillovers and how existing economic structures shape future intraurban localization and employment and are in line with traditional approaches to localization economies at regional level (cf. [62]). Given that Göteborg traditionally has relied on manufacturing and now increasingly is dominated by service sector jobs [39] and since different types of sectors were affected differently during the recession in 1992 and 2001 (manufacturing and service, resp.), we argue that these indicators together control such varying processes that may shape future employment geographies.

Moreover, also more neighbourhood-specific factors may influence the goal variable and needs to be considered in the analysis. For example, the preexisting distribution of jobs and residents may influence where future jobs are created due to mass and the realization of scale economies as is often the case in regional studies [63]. Therefore two indicators of people employed and resident in each area 1990, respectively, are created. We expect that employment growth primarily should be correlated with previous concentrations of employment rather than residents due to mass and existing infrastructure that may facilitate endogenous growth. Furthermore, more qualitative neighbourhood characteristics may also influence future employment, for example, the cost of land as well as commercial and real estate prices. Since data on this unfortunately is unavailable, this cannot be directly captured in the models. However, by assuming that real estate prices are correlated with the income level of the population (higher incomes of the population in an area reflect higher real estate prices) and also proxy relative attractiveness we include the change in mean income of the residents in each area (cf. [64]). Similarly, the mean income of workers in each area is used as a proxy for commercial prices. This builds on the assumption that firms employing high-wage earners are more likely to be found in attractive urban areas due to the relative amenities available (e.g., [17]). Finally, as several other studies estimating employment growth, an indicator of the number of workers compared to the number of plants (PlantComp) is added (e.g., [50]). While this indicator on one hand can control for competition, Bishop [56] argues that it also reflects average size which makes it difficult to disentangle scale effects from competitive effects. Since our four location quotients can be argued to both measure specialization as well as competition we expect this indicator to more readily capture the scale effect within the Göteborg metropolitan area. Definitions of all variables together with descriptive statistics are displayed in Table 2. It should be noted that we also initially included an indicator for population density to control for mass and the realization of scale-economies as is often the case in regional studies [63]. This indicator was however not significant in either model and did not influence the estimates of either of the right-hand side variables and was therefore omitted from the final analysis.

3.2. Econometric Model and Findings. OLS models have been estimated to test for the relationships between human capital levels and the composition of skills, respectively, on employment change within each of the 84 PUA (described in detail above). Since these areas are relatively small compared to labour markets or even municipalities in terms of both spatial range and number of employees, and because the function of each area is based on the spatial division of activities within the metropolitan economy, there is a risk that spatial autocorrelation issues may arise. (An alternative way to handle the spatial autocorrelation would be to estimate the models as hierarchical two-level multilevel models [65]. However, a subsequent likelihood ratio-test revealed that the OLS was more efficient than the multilevel model, which made us decide not to apply a multilevel approach.) For example, due to the internal division of economic activities the residuals may not be random since the internal division urban functions are clustered within the city meaning that the basic assumption of the OLS would not hold [66]. A solution to handle this issue is using cluster robust standard errors that let the standard errors covariate at higher spatial levels and thereby relax the assumption on correlation (cf. [67]). We therefore let the standard errors covariate on the district level $(N=8)$, which both geographically and functionally binds different areas to each other (as displayed in Table 1) and thereby we acknowledge the fact that spillovers may cross intraurban boundaries. Moreover, when estimating 
TABle 2: Variable definitions and descriptive statistics. All variables are measured in year 1990 if not stated otherwise.

\begin{tabular}{|c|c|c|c|c|c|}
\hline Variable & Definition & Mean & Std. Dev. & Min & Max \\
\hline \multicolumn{6}{|l|}{ Dependent variables } \\
\hline Emp9093 & Employment change (\%) in 1990-93 (log) & -0.16 & 0.19 & -1.25 & 0.87 \\
\hline Emp9000 & Employment change (\%) in 1990-00 (log) & -0.10 & 0.51 & -1.89 & 1.00 \\
\hline Emp9008 & Employment change (\%) in 1990-08 (log) & 0.09 & 0.51 & -1.49 & 2.22 \\
\hline \multicolumn{6}{|l|}{ Human capital } \\
\hline HumanCap & Share (\%) of workers with at least bachelor's degree (log) & -1.33 & 0.34 & -2.81 & -0.63 \\
\hline SkillCompLQ & Concentration of creative workers compared to city (LQ) & 1.04 & 0.44 & 0.32 & 2.62 \\
\hline SkillCompLQ2 & Concentration of creative workers compared to city (LQ), squared & 1.26 & 1.26 & 0.10 & 6.88 \\
\hline \multicolumn{6}{|l|}{ Controllers } \\
\hline EmpLog & Total number of people employed in area in 1990 (log) & 8.56 & 1.01 & 4.53 & 10.13 \\
\hline PopLog & Total number of people resident in area in $1990(\mathrm{log})$ & 8.21 & 1.10 & 2.94 & 9.19 \\
\hline EIncGrowth9093 & Change (\%) in mean income of employed people in area 1990-93 & 0.99 & 0.06 & 0.81 & 1.49 \\
\hline PIncGrowth9093 & Change (\%) in mean income of residents in area 1990-93 & 0.87 & 0.08 & 0.57 & 1.09 \\
\hline EIncGrowth9000 & Change (\%) in mean income of employed people in area 1990-00 & 1.20 & 0.09 & 0.86 & 1.49 \\
\hline PIncGrowth9000 & Change (\%) in mean income of residents in area $1990-00$ & 1.13 & 0.17 & 0.60 & 1.46 \\
\hline EIncGrowth9008 & Change (\%) in mean income of employed people in area 1990-08 & 1.36 & 0.17 & 0.84 & 1.83 \\
\hline PIncGrowth9000 & Change (\%) in mean income of residents in area 1990-08 & 1.26 & 0.24 & 0.23 & 1.70 \\
\hline LQ_KM & Concentration of knowledge intensive manufacturing (LQ) & 0.85 & 1.36 & 0.00 & 5.36 \\
\hline LQ_LM & Concentration of labour intensive manufacturing (LQ) & 0.99 & 1.57 & 0.00 & 8.35 \\
\hline LQ_BS & Concentration of business related services (LQ) & 1.13 & 1.07 & 0.00 & 6.10 \\
\hline LQ_LS & Concentration of labour intensive services (LQ) & 1.02 & 0.53 & 0.08 & 2.54 \\
\hline PlantCompLog & Number of employees per plant (log) & 3.23 & 0.75 & 1.34 & 6.61 \\
\hline
\end{tabular}

means derived from a varying number of observations, this may imply that areas with averages based on only a few observations contain variance in residuals that are greater and hence more imprecise than those calculated from a greater number of observations. Following Cameron and Trivedi's [67] suggestion, we have therefore weighted our models on total population size (employed plus residents).

The empirical results for employment growth are presented in Table 3. All goodness of fit tests is satisfactory, suggesting that the models do explain some of the variation in employment growth during the three periods. The significant RESET $F$-test for omitted variable bias however suggests a specification error, particularly in the two first models that estimate employment growth between 1990 and 1993. This is reduced by excluding the income variables (both are insignificant) and including a variable on income levels in 1990. However, since that variable is strongly correlated to human capital level which caused severe multicollinearity and since excluding or including either of these variables did not influence the estimation scores on either variable or influence the explanatory power, we decided to keep the original setup of controllers. After having logged some of the variables (see Table 2), neither tests for skewness nor kurtosis revealed any problematic deviations from the assumed normal distribution. Together with the correlation matrix (see Tables 4 and 5), the VIF test indicates that multicollinearity is not influencing the models to any great extent. The only indicators with a tolerance $<0.3$ are the two indicators for skill composition (0.12 and 0.11, resp.).
Concerning employment growth during the recession (1990-1993), we find that human capital has a positive influence on employment. This together with the negative scores of the two manufacturing LQ:s suggests that it mainly was "blue-collar jobs" that suffered from the recession. As noted earlier, attracting human capital [6], which in turn generates knowledge spillovers, appears to have stimulated growth in this case. However, it can be concluded that all segments of the economy were influenced by the recession since also areas with high concentrations of business related services suffered during the recession. As we see areas characterized by a strong local specialization, for example, areas with high concentrations of business related services, being hit hard by the recession, it is reasonable to state that a lack of Jacobs externalities [18] (a diversified local knowledge and economic base) results in weakened resilience towards external shocks such as economic downswings. The manufacturing sector in Göteborg is dominated by automotive industry with a substantial presence of specialized suppliers in close proximity which could explain the halted employment growth in knowledge- and labour-intensive manufacturing. As indicated by the negative score of PlantComp, it was mainly large plants that contracted during the recession. Smaller firms were more affected between 1990 and 1993 and responded by aborting hiring processes. As expected, new employment during the recession was mainly found in the areas with high employment levels in 1990 while areas with high level of residents were less well off. We find no evidence that land values proxied as change in mean income 
TABLE 3: OLS models on area level employment change in Göteborg between 1990 and 1993/2000/2008, respectively. Coefficients and clusterrobust standard errors (within brackets) are reported. Significant at $0.1\left({ }^{*}\right), 0.05\left({ }^{* *}\right)$, and $0.01\left(^{* * *}\right)$ levels.

\begin{tabular}{lcccccc}
\hline & Emp9093A & Emp9093B & Emp9000A & Emp9000B & Emp9008A & Emp9008B \\
\hline HumanCap & $0.230^{* *}(0.098)$ & & $0.542^{* * *}(0.154)$ & & $0.352(0.264)$ & \\
SkillCompLQ & & $0.248(0.138)$ & & $1.365^{* * *}(0.233)$ & & $1.325^{* * *}(0.377)$ \\
SkillCompLQ2 & & $-0.064(0.042)$ & & $-0.427^{* * *}(0.091)$ & & $-0.449^{* * *}(0.106)$ \\
EmpLog & $0.066^{* *}(0.021)$ & $0.083^{* *}(0.026)$ & $0.017(0.045)$ & $0.027(0.054)$ & $0.031(0.061)$ & $0.006(0.069)$ \\
PopLog & $-0.050^{* *}(0.018)$ & $-0.057^{* *}(0.019)$ & $-0.054(0.059)$ & $-0.073(0.061)$ & $-0.075(0.054)$ & $-0.099(0.054)$ \\
EIncGrowth & $-0.223(0.714)$ & $-0.372(0.667)$ & $2.714^{* *}(0.954)$ & $2.700^{* *}(0.933)$ & $1.760^{* *}(0.525)$ & $1.819^{* * *}(0.477)$ \\
PIncGrowth & $-0.052(0.154)$ & $0.027(0.182)$ & $-0.912(0.644)$ & $-0.741(0.659)$ & $-0.009(0.337)$ & $0.095(0.315)$ \\
LQ_KM & $-0.035^{*}(0.020)$ & $-0.064^{* *}(0.022)$ & $-0.100^{* *}(0.046)$ & $-0.187^{* * *}(0.034)$ & $-0.027^{* *}(0.050)$ & $-0.091^{* * *}(0.018)$ \\
LQ_LM & $-0.031^{*}(0.015)$ & $-0.041^{* * *}(0.011)$ & $0.003^{* *}(0.034)$ & $0.027^{* *}(0.031)$ & $0.015^{*}(0.061)$ & $0.005^{*}(0.056)$ \\
LQ_BS & $-0.144^{* * *}(0.022)$ & $-0.147^{* * *}(0.023)$ & $0.004(0.030)$ & $-0.016(0.051)$ & $0.049(0.034)$ & $0.017(0.056)$ \\
LQ_LS & $-0.000(0.055)$ & $-0.069(0.039)$ & $-0.036(0.118)$ & $-0.142(0.148)$ & $-0.139(0.131)$ & $-0.009(0.153)$ \\
PlantCompLog & $-0.145^{* * *}(0.029)$ & $-0.151^{* * *}(0.033)$ & $-0.257^{* *}(0.105)$ & $-0.268^{* *}(0.099)$ & $-0.191^{* *}(0.071)$ & $-0.225^{* *}(0.091)$ \\
Intercept & $0.954(0.684)$ & $0.588(0.823)$ & $-0.157(0.805)$ & $-1.814(0.988)$ & $-0.523(0.830)$ & $-1.758(1.017)$ \\
$R^{2}$ & 0.579 & 0.539 & 0.645 & 0.665 & 0.544 & 0.586 \\
F-test & $15.77^{* * *}$ & $11.39^{* * *}$ & $14.02^{* * *}$ & $13.79^{* * *}$ & $5.84^{* * *}$ & $5.94^{* * *}$ \\
RESET F-test & $3.22^{* *}$ & $3.11^{* * *}$ & $1.88^{* *}$ & $1.72^{*}$ & 1.54 & 1.30 \\
Mean VIF & 1.79 & 5.68 & 1.74 & 5.41 & 1.82 & 5.49 \\
$N$ & 84 & 84 & 84 & 84 & 84 & 84 \\
\hline
\end{tabular}

of workers or residents should influence employment growth. Finally, the second model indicates that the composition of skills within PUA did not influence employment during this period. This is a finding that runs contrary to the literature on evolutionary economic geography [9], stressing the importance of complementary skills and composition rather than mass or specialization/diversification.

However, during the period from 1990 to 2000, a somewhat different picture emerges. Human capital is still significant but so is also the composition of skills. As expected, the estimates indicate a nonlinear relationship with employment in which an increasing relative concentration of creative occupations is positively related to employment growth but only to about 1.3 (about one S.D. from mean) when the relationship turns negative again. The bell shape of this relationship thus indicates that a concentration of creative occupations approximately one S.D. from the city mean (mean: 1.0) is most beneficial for employment, and hence pointing in the direction of a "Jacobs-oriented" diversified local economy. Thus, together with the results in previous models (1990-1993), these two models indicate that areas with already high concentrations of human capital handled the recession well and that employment continued to rise in these areas during the recovery until the burst of the IT-bubble. The geography of talents, as noted earlier by [2], is therefore important to acknowledge based on our findings that spatial concentrations of human capital are comparatively resilient to economic crisis. However, also skill composition is of importance and by comparing the $\mathrm{R}^{2}$ of the two models it seems as if composition had a slightly higher influence on employment growth than human capital concentrations per se. Furthermore, while high relative concentrations of knowledge intensive manufacturing still show a negative relationship with employment growth, the negative sign on labour intensive manufacturing for the period 19901993 has now changed to a positive sign indicating that new employment opportunities are present in such areas. Business related services are however no longer significant which indicates that new jobs were not created during the recovery in areas already specialized in business services. A large share of employment generated in this sector in Göteborg occurred in areas previously characterized by manufacturing, for example, the waterfront, and hence indicating a local transition from heavy industry to services. A growing service industry [5] is a vital part of the structural economic change occurring throughout the time period in Göteborg. Large employers such as Ericsson (telecommunications), Volvo (automotive industry), and Chalmers (technological university) all established research facilities at Lindholmen, the eastern part of the redeveloped waterfront, in the time period 1999-2003 serve to explain a positive location quotient in 2000 (and also in 2008). This notion is confirmed together with the nonsignificant score on employment levels 1990 and the positive sign of workers income growth, which indicates that employment grew faster in areas that previously did not have such high employment levels. Still, the division between residential areas and business areas is evident since neither population concentrations in 1990 nor income growth of residents shows any significant relationship with employment growth. Finally, the estimation score of PlantComp indicates that it predominantly was small firms that induced employment growth during this period.

For employment growth in 1990-2008, we find that levels of human capital have no significant relationship with employment while the composition of skills has. Also here the relationship follows the pattern of an inverted U-shape 


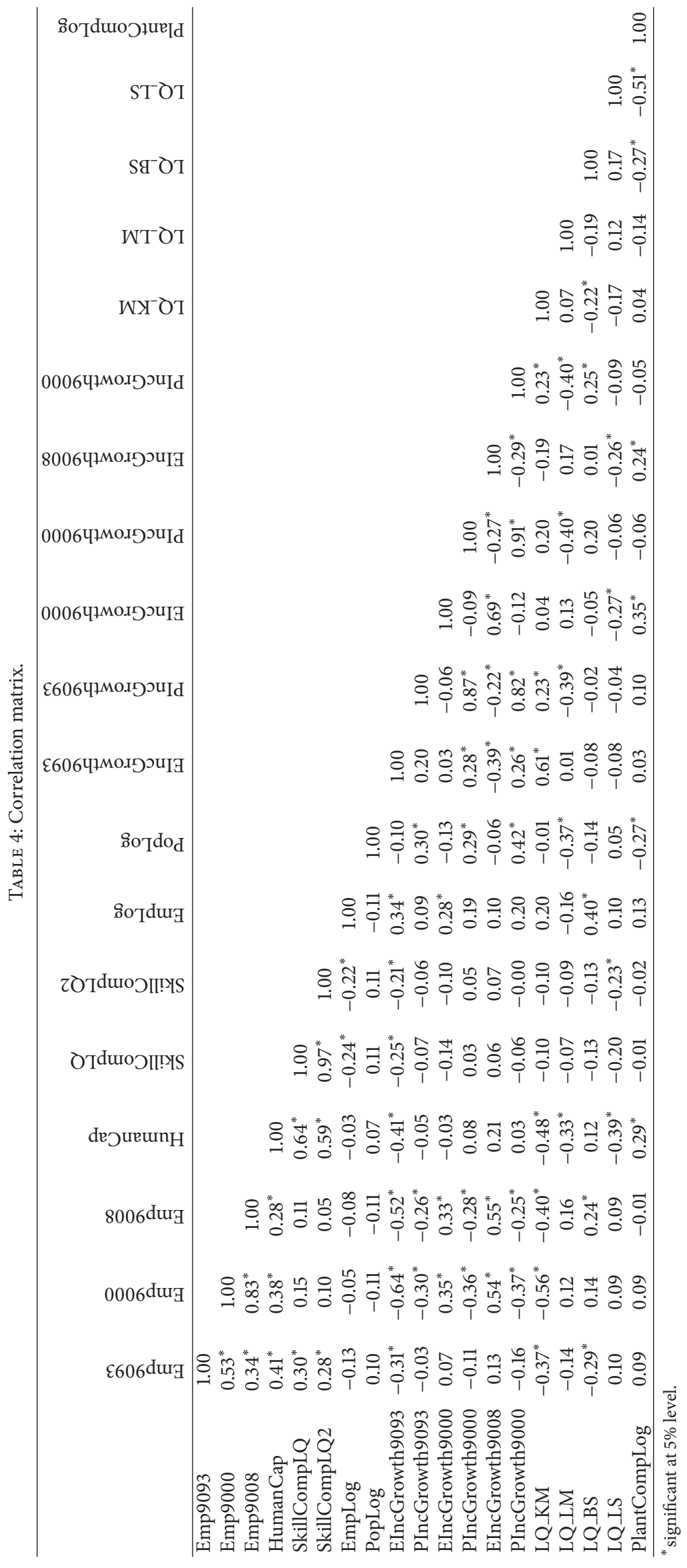


TABLE 5: List of educations comprising core.

Description
Pedagogy and teachers school, general type
Pedagogy
Teachers school, preschool
Teachers school, grades 1-9
Teachers school, grades 1-9, specialized
Teachers school, gymnasium (nonmandatory grades 10-12)
Specialized pedagogy, school administration
Arts and media, history and science of arts, music, media
production, design, and artistic crafts
Humanities, theology, linguistics and language, Swedish and
history of literature, history and archeology, and philosophy and
logic
Behavioral science, psychology, sociology, anthropology,
geography, political science, and economics
Journalism, communication, library science, and information
Marketing
Biology, environmental science, nutrition, pharmacology, and
biochemistry
Physics, chemistry, and geoscience
Mathematics and statistics
Computer science
Engineering
Medical school
Dentist school
Optician and biomedical analyst
Tot

Note: List of the educations that make up core, based on the highest reported type of education. In the case of an individual having more than one education, it is always the latest that is reported. The code consists of a threedigit code and reveals type length. Descriptions are translated into English and should be considered as approximations.

peaking at 1.6 and then declining (almost two S.D.s from the city average). In other words, the results indicate that neither too great concentrations of creative occupations nor too little ones are beneficial to generate significant spillovers. It is, in contrary to, for example, Glaeser et al. [6], the mix of worker skills rather than human capital concentrations per se in 1990 that promotes more long-term employment growth. During this period, relative concentrations of knowledge intensive manufacturing as well as plant competition still show negative relationship with employment growth while areas with increasing mean wages still influence employment positively as do areas with labor intensive manufacturing (e.g., industrial PUA in the north of Göteborg dominated by automotive industry) in 1990. Moreover, as in previous models neither income growth of residents nor number of residents in 1990 influences employment growth. Also for 2008 the findings indicate that jobs primarily were created in new growing areas. Based on this, we find that the redeveloped waterfront, place-marketed and reborn through the staging of events [40], is a powerful driver of employment growth in Göteborg during the studied time period.

\section{Concluding Remarks}

This paper has addressed how the composition of urban talent and changing skills is related to the dynamics of intraurban employment in Göteborg, Sweden, between 1990 and 2008. Both the descriptive analysis and the regression results indicate that the composition of urban talent, operationalized as creative educations, follows a spatial division in the city region resulting in uneven geographies of talent. Furthermore, we find that different area-specific attributes have different influence on employment over the economic cycle. In particular, concentrations of human capital were more beneficial over the recession and early recovery while the composition of skills is in the longer run (over two periods of growth), especially a composition close to the mean of the city, with slight overweight to core. Aligned with previous empirical studies inspired by Florida [8], we do find that relative concentrations of creative skills (core) are associated with economic development. The results however indicate that too high concentrations of creative skills are not beneficial and that significant spillovers are derived in areas with a mixed population.

As education has been argued a close proxy of the "creative class" $[2,8,68]$ and operationalized as such in this paper, we on one hand find that an argument could be made in favour of a Glaeser-view of urban economic development, emphasizing the importance of large shares of educated professionals among the working population rather than creative professionals. However this is only temporary as the analysis shows. Instead, it is a composition of creative and "noncreative" skills resembling the city average that matters in the long run which offers support for Jacobs's theories on the benefits of a mixed local economy, that is, a variety in divisions of skills and labour, in order to attract, for example, more goods and services that in turn should trigger future intraurban employment. The waterfront location of Norra Älvstranden exemplifies this long-term development and illustrates the spatial concentrations of talents and skills to a few sites within the urban space economy. Returning to the issue at hand in this paper, that is, studying the factors explaining intraurban employment growth, we find that it is the revitalized areas of Göteborg, for example, the waterfront location, rather than the preexisting areas of human capital through endogenous growth that drive the urban economy. Containerization [43] and fierce competition for downtown office space [39] can be attributed to much of this transition in Göteborg as it provides the motive and the means for locating incubation grounds and start-ups on new locations. Having said this, the influence of local and regional long-term planning strategies in shaping the transition from manufacturing to residences and offices at the waterfront plays an important part. Thus, an interesting topic of future research would be to enquire into the causality of the human capital located at the waterfront in relation to long-term planning goals. In other words, is the distribution of talents, human capital and skills an effect of long-term planning executed on an intraurban level or is it the opposite, that is, a matter of policies adapting to the location of individuals? Meanwhile, the manufacturing sector in Göteborg remains 
located on the same sites and in the same areas indicating path dependency [69]. It is reasonable to assume that local environmental regulations and congestion issues as well as availability of land affects the location of industrial activity in Göteborg as well as in other comparable Swedish cities.

The case of Göteborg has showed that the intraurban composition of talents needs to correspond to the city's in order to act beneficial on employment growth. This implies that the distribution of talents on the city level serves as a bench-mark, however, not revealing anything of the actual composition of talents in each PUA, for what could be considered a favourable mix of individuals. This is a case in point as much of the literature has focused on the broad brushstrokes, only narrowing in on a few success stories, when telling the story of the postindustrial knowledge economy $[8,70]$. We find that it is PUA with a balanced composition of core and comparison group, and also of skills, that have an impact on employment growth in the long perspective, from 1990 to 2008.

While having revealed the intraurban complexity of employment growth and that human capital and the composition of skills matter differently over time, there are still some aspects that this study fails to cover and that could inspire future research. It is reasonable to expect that the destruction of existing employment and the creation of new jobs are concealed when analysing net changes in employment [71]. It is also likely that this varies greatly across different sectors (some decline and others grow). It would therefore be interesting to address the intraurban evolution of specific sectors to assess where certain activities grow and replace old jobs. As noted earlier, in the case of the waterfront in Göteborg new sectors have evolved and replaced older sectors. In relation to the evolution of job creation and destruction, future studies could also focus on the types of jobs that are destructed and created and how that is linked to wider processes of flexibilisation and divisions of labour within cities [72]. Given the macrofindings by Holmlund and Storrie [73], it is reasonable to expect that many of the created jobs are based on fixed-term contracts but where these types of jobs are created and for which groups remains to be seen. Moreover, by studying the geography of entrepreneurship and spin-offs [69] it would be possible to discern in more detail how the intraurban economy evolves if addressing questions like where new firms of various forms (start-ups of spin-offs) in different sectors enter and how the location of entrepreneurship influences survival power and employment growth [74].

\section{Conflict of Interests}

The authors declare that there is no conflict of interests regarding the publication of this paper.

\section{References}

[1] D. Massey, Spatial Divisions of Labour: Social Structures and the Geography of Production, Macmillan, London, UK, 1984.

[2] H. K. Hansen and L. Winther, "The spatial division of talent in city regions: location dynamics of business services in
Copenhagen," Tijdschrift voor Economische en Sociale Geografie, vol. 101, no. 1, pp. 55-72, 2010.

[3] J. Henderson, "A negotiated landscape: the transformation of San Francisco's Waterfront Since 1950 (Jasper Rubin)," Urban Geography, vol. 33, no. 5, pp. 756-758, 2012.

[4] W. B. Beyers, "Services and the new economy: elements of a research agenda," Journal of Economic Geography, vol. 2, no. 1, pp. 1-29, 2002.

[5] G. Rusten and J. R. Bryson, "Placing and spacing services: towards a balanced economic geography of firms, clusters, social networks, contracts and the geographies of enterprise," Tijdschrift voor Economische en Sociale Geografie, vol. 101, no. 3, pp. 248-261, 2010.

[6] E. L. Glaeser, H. D. Kallal, J. A. Scheinkman, and A. Schleifer, "Growth in cities," Journal of Political Economy, vol. 100, no. 6, pp. 1126-1152, 1992.

[7] T. N. Clark, R. Lloyd, K. K. Wong, and P. Jain, "Amenities drive urban growth," Journal of Urban Affairs, vol. 24, no. 5, pp. 493$515,2002$.

[8] R. Florida, The Rise of the Creative Class: and How It's Transforming Work, Leisure, communIty and Everyday Life, Basic Books, New York, NY, USA, 2002.

[9] K. Frenken, F. Van Oort, and T. Verburg, "Related variety, unrelated variety and regional economic growth," Regional Studies, vol. 41, no. 5, pp. 685-697, 2007.

[10] R. Boschma and S. Iammarino, "Related variety, trade linkages, and regional growth in Italy," Economic Geography, vol. 85, no. 3, pp. 289-311, 2009.

[11] P. Bishop and P. Gripaios, "Spatial externalities, relatedness and sector employment growth in Great Britain," Regional Studies, vol. 44, no. 4, pp. 443-454, 2010.

[12] R. Eriksson and H. K. Hansen, "Industries, Skills and human capital: how does regional size affect uneven development?" Environment and Planning A, vol. 45, no. 3, pp. 593-613, 2013.

[13] R. Boschma, R. Eriksson, and U. Lindgren, "How does labour mobility affect the performance of plants? The importance of relatedness and geographical proximity," Journal of Economic Geography, vol. 9, no. 2, pp. 169-190, 2009.

[14] G. Törnqvist, Kreativitetens Geografi [the Geography of Creativity], SNS Förlag, Stockholm, Sweden, 2004.

[15] T. A. Hutton, The New Economy of the Inner City: Restructuring, Regeneration and Dislocation in the Twenty-First-Century Metropolis, Routledge, London, UK, 2008.

[16] G. S. Becker, Human Capital, Columbia University Press, New York, NY, USA, 1964.

[17] E. L. Glaeser, "The new economics of urban and regional growth," in Oxford Handbook of Economic Geography, G. L. Clark, M. P. Feldman, and M. S. Gertler, Eds., pp. 83-98, Oxford University Press, Oxford, UK, 2000.

[18] J. Jacobs, The Economy of Cities, Vintage, New York, NY, USA, 1969.

[19] S. Sassen, The Global City: New York, London, Tokyo, Princeton University Press, Princeton, NJ, USA, 2nd edition, 2001.

[20] M. P. Smith, Transnational Urbanism: Locating Globalization, Blackwell, Oxford, UK, 2001.

[21] J. Borggren, Kreativa individers bostadsområden och arbetsställen. Belysta mot bakgrund av näringslivets omvandling och förändringar i bebyggelsestrukturen i Göteborg, Department of Human and Economic Geography, University of Gothenburg, 2011. 
[22] P. Dicken, Global Shift. Mapping the Changing Contours of the World Economy, SAGE Publications, London, UK, 6th edition, 2011.

[23] R. H. Eriksson and F. Forslund, "How do universities contribute to employment growth? The role of human capital and knowledge bases," European Planning Studies, 2013.

[24] J. R. Abel and R. Deitz, "Do colleges and universities increase their region's human capital?" Journal of Economic Geography, vol. 12, no. 3, pp. 667-691, 2012.

[25] A. Marshall, Principles of Economics, Macmillan, London, UK, 1890.

[26] R. E. Lucas Jr., "On the mechanics of economic development," Journal of Monetary Economics, vol. 22, no. 1, pp. 3-42, 1988.

[27] P. Romer, "Endogenous technological change," Journal of Economic History, vol. 98, pp. S71-S102, 1990.

[28] J. E. Rauch, "Productivity gains from geographic concentration of human capital: evidence from the cities," Journal of Urban Economics, vol. 34, no. 3, pp. 380-400, 1993.

[29] E. Moretti, "Estimating the social return to higher education: evidence from longitudinal and repeated cross-sectional data," Journal of Econometrics, vol. 121, no. 1-2, pp. 175-212, 2004.

[30] J. V. Winters, "Human capital externalities and employment differences across metropolitan areas of the USA," Journal of Economic Geography Advance Axess, vol. 12, pp. 1-24, 2012.

[31] R. H. Eriksson, "Localized spillovers and knowledge flows: how does proximity influence the performance of plants?" Economic Geography, vol. 87, no. 2, pp. 127-152, 2011.

[32] R. Pendall, K. A. Foster, and M. Cowell, "Resilience and regions: building understanding of the metaphor," Cambridge Journal of Regions, Economy and Society, vol. 3, no. 1, pp. 71-84, 2010.

[33] R. Martin, "Regional economic resilience, hysteresis and recessionary shocks," Journal of Economic Geography, vol. 12, no. 1, pp. 1-32, 2012.

[34] A. Markusen, "Fuzzy concepts, scanty evidence, policy distance: the case for rigour and policy relevance in critical regional studies politiques pertinentes dans les études régionales critiques," Regional Studies, vol. 37, no. 6-7, pp. 701-717, 2003.

[35] J. Essletzbichler, Diversity, Stability and Regional Growth in the US (1975-2002), Papers in Evolutionary Economic Geography no 0513 , Utrecht University, Section of Economic Geography, 2005.

[36] J. Borggren and P. Ström, On the Waterfront: Creative Individuals' Work-Places and Residences at Norra Älvstranden, Local Economy Forthcoming, Gothenburg, Sweden, 2014.

[37] B. Nooteboom, Learning and Innovation in Organizations and Economies, Oxford University Press, Oxford, UK, 2000.

[38] P. Desrochers and S. Leppälä, "Opening up the "Jacobs spillovers" black box: local diversity, creativity and the processes underlying new combinations," Journal of Economic Geography, vol. 11, no. 5, pp. 843-863, 2011.

[39] Business Region Göteborg, Tillväxt i Göteborgsregionen (Growth in the Göteborgregion), BRG, Göteborg, Sweden, 2007.

[40] G.-J. Hospers, "Place marketing in shrinking Europe: some geographical notes," Tijdschrift voor Economische en Sociale Geografie, vol. 102, no. 3, pp. 369-375, 2011.

[41] D. Harvey, "From managerialism to entrepreneurialism: the transformation in urban governance in late capitalism," Geografiska Annaler: Series B, vol. 71, no. 1, pp. 3-17, 1989.

[42] Swedish Trade Council, "Västra Götaland är landets största exportlän. [Västra Götaland is the leading exportregion.]," http://www.swedishtrade.se/sv/smaforetag/regionalaexportradgivare/Exportstatistik/Vastra-Gotaland/.

[43] C. Hahn, "Die neue urbane Waterfront-ein Stadtteil für alle?" Europa Regional, vol. 17, no. 1, pp. 25-33, 2009.

[44] B. Hoyle, "Global and local change on the port-city waterfront," Geographical Review, vol. 90, no. 3, pp. 395-417, 2000.

[45] J. Söderlind, Stadens renässans: från särhälle till samhälle: om närhetsprincipen i stadsplaneringen, SNS, Stockholm, Sweden, 1998.

[46] B. Öhrström, Uban Processes and Global Competition-Enabling Factors fr Mutual Urban and Economic Development at Norra Älvstranden in Göteborg, Göteborg, Department of Urban Design and Development School of Architecture, 2004.

[47] K. Hedin, E. Clark, E. Lundholm, and G. Malmberg, "Neoliberalization of housing in Sweden: fentrification, filtering, and social polarization," Annals of the Association of American Geographers, vol. 102, no. 2, pp. 443-463, 2012.

[48] R. Andersson, J. M. Quigley, and M. Wilhelmson, "University decentralization as regional policy: the Swedish experiment," Journal of Economic Geography, vol. 4, no. 4, pp. 371-388, 2004.

[49] Statistics Sweden, Statistical Yearbook for Sweden, vol. 81, Publikationstjänsten (SCB), Stockholm, Sweden, 1994.

[50] S. Deidda, R. Paci, and S. Usai, Spatial Externalities and Local Economic Growth Contribiti di Ricerca No. 02/06, Centro Ricerche Economiche Nord Sud (CRENoS), Cagliari, Italy, 2006.

[51] City of Göteborg, “Områdesindelningar i Göteborg," 2012, http://www4.goteborg.se/.

[52] S. Openshaw, The Modifiable Areal Unit Problem, Geo Books, Norwick, UK, 1983.

[53] City of Gothenburg, "Kommunfullmäktige sa ja till SDNreformen. Vårt Göteborg," 2010, http://www.vartgoteborg.se/ $\operatorname{prod} / \mathrm{sk} /$.

[54] L. Hedman and G. Galster, "Neighbourhood income sorting and the effects of neighbourhood income mix on income: a holistic empirical exploration," Urban Studies, vol. 50, no. 1, pp. 107-127, 2013.

[55] City of Göteborg, "Områdesfakta/Göteborgsbladet. Göteborgs stads statistikdatabas på Internet," 2011, http://www4.goteborg.se/prod/G-info/statistik.nsf.

[56] P. Bishop, "Spatial spillovers and employment growth in the service sector," Service Industries Journal, vol. 29, no. 6, pp. 791803, 2009.

[57] R. C. Kloosterman and S. Musterd, "The polycentric urban region: towards a research agenda," Urban Studies, vol. 38, no. 4, pp. 623-633, 2001.

[58] N. A. Phelps and N. Parsons, "Edge urban geographies: notes from the margins of Europe's capital cities," Urban Studies, vol. 40, no. 9, pp. 1725-1749, 2003.

[59] Statistics Sweden, Folk- och Bostadsräkningen 1990, FoB 90, Report, 1999, http://www.scb.se/statistik/BE/BE0205/_dokument/BE0205_DO_1990.pdf.

[60] Statistics Sweden, Tema: Utbildning-Sambandet mellan utbildning och yrke, Statistics Sweden (SCB), Örebro, Sweden, 2007.

[61] Jones Lang LaSalle, "Nordic City Report Autumn 2012," 2012, http://www.sipa.nu/pdf/jll_nordicCityMarket_2012.pdf.

[62] A. Malmberg, B. Malmberg, and P. Lundequist, "Agglomeration and firm performance: economies of scale, localisation, and urbanisation among Swedish export firms," Environment and Planning A, vol. 32, no. 2, pp. 305-321, 2000. 
[63] J. H. L. Dewhurst and P. McCann, "Specialization and regional size," in Proceedings of the the ESRC Urban and Regional Economics Seminar Group Meeting, Carlisle, UK, 2006.

[64] R. B. Peiser, "The determinants of nonresidential urban land values," Journal of Urban Economics, vol. 22, no. 3, pp. 340-360, 1987.

[65] M. Semyonov and N. Lewin-Epstein, "The declining racial earnings' gap in United States: multi-level analysis of males' earnings, 1960-2000," Social Science Research, vol. 38, no. 2, pp. 296-311, 2009.

[66] P. Rogerson, A Statistical Methods for Geography: A Student's Guide, SAGE Publications, London, UK, 2010.

[67] A. C. Cameron and P. K. Trivedi, Microeconometris Using Stata, Stata Press Books, Statacorp LP, 2010.

[68] H. K. Hansen and T. Niedomysl, "Migration of the creative class: evidence from Sweden," Journal of Economic Geography, vol. 9, no. 2, pp. 191-206, 2009.

[69] S. Klepper, "The capabilities of new firms and the evolution of the US automobile industry," Industrial and Corporate Change, vol. 11, no. 4, pp. 645-666, 2002.

[70] A. Saxenian, Regional Advantage. Culture and Competition in Silicon Valley and Route 128, Harvard University Press, Cambridge, Mass, USA, 1994.

[71] J. Essletzbichler, "The geography of job creation and destruction in the U.S. manufacturing sector, 1967-1997," Annals of the Association of American Geographers, vol. 94, no. 3, pp. 602-619, 2004.

[72] D. Harvey, A Brief History of Neoliberalism, Oxford University Press, Oxford, UK, 2005.

[73] B. Holmlund and D. Storrie, "Temporary work in turbulent times: the Swedish experience," Economic Journal, vol. 112, no. 480, pp. F245-F269, 2002.

[74] M. Fritsch and Y. Schindele, "The contribution of new businesses to regional employment-an empirical analysis," Economic Geography, vol. 87, no. 2, pp. 153-180, 2011. 

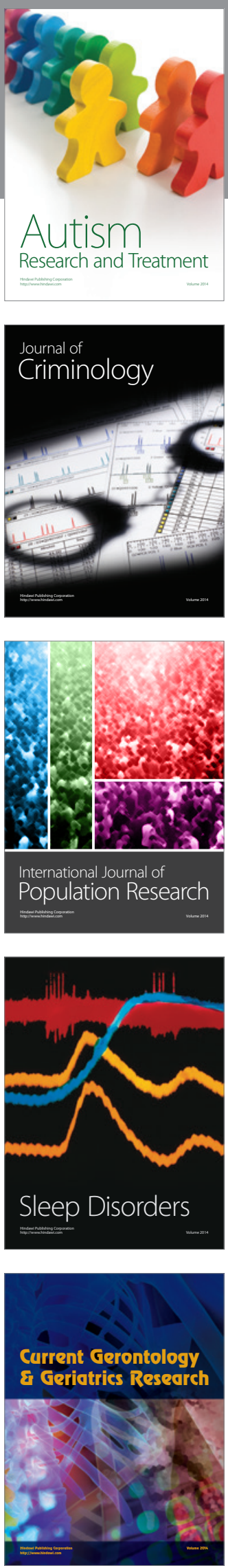
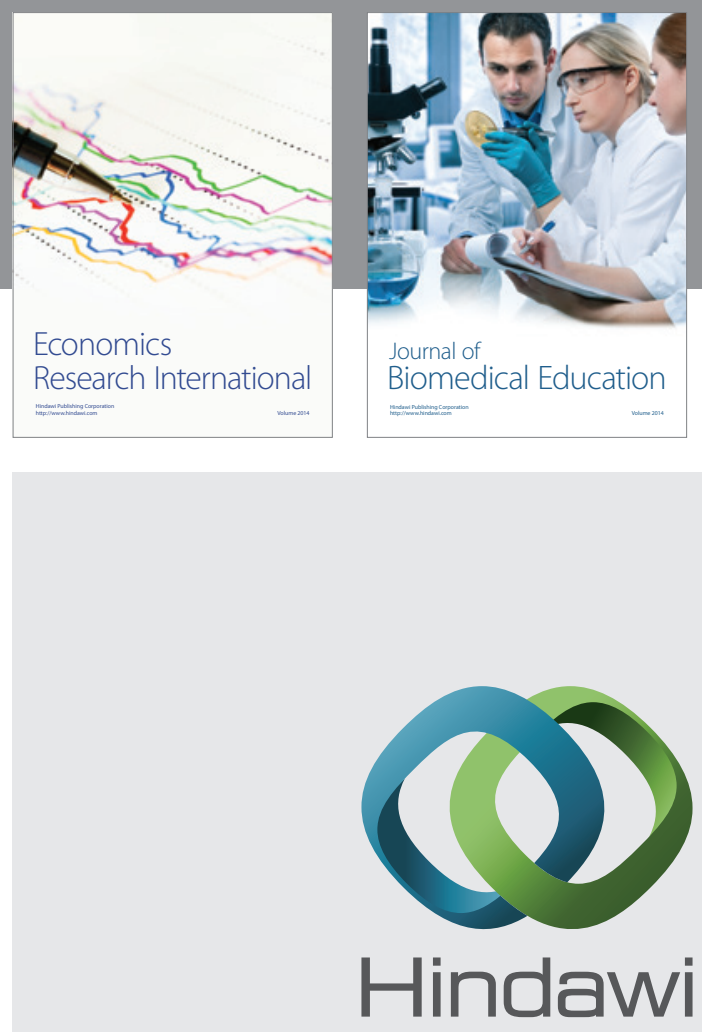

Submit your manuscripts at

http://www.hindawi.com
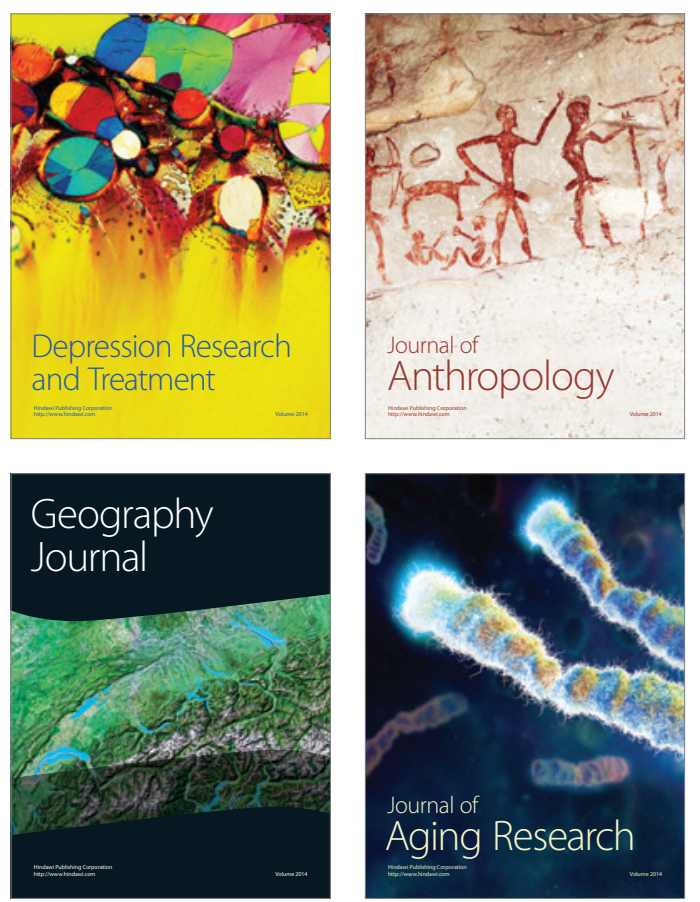
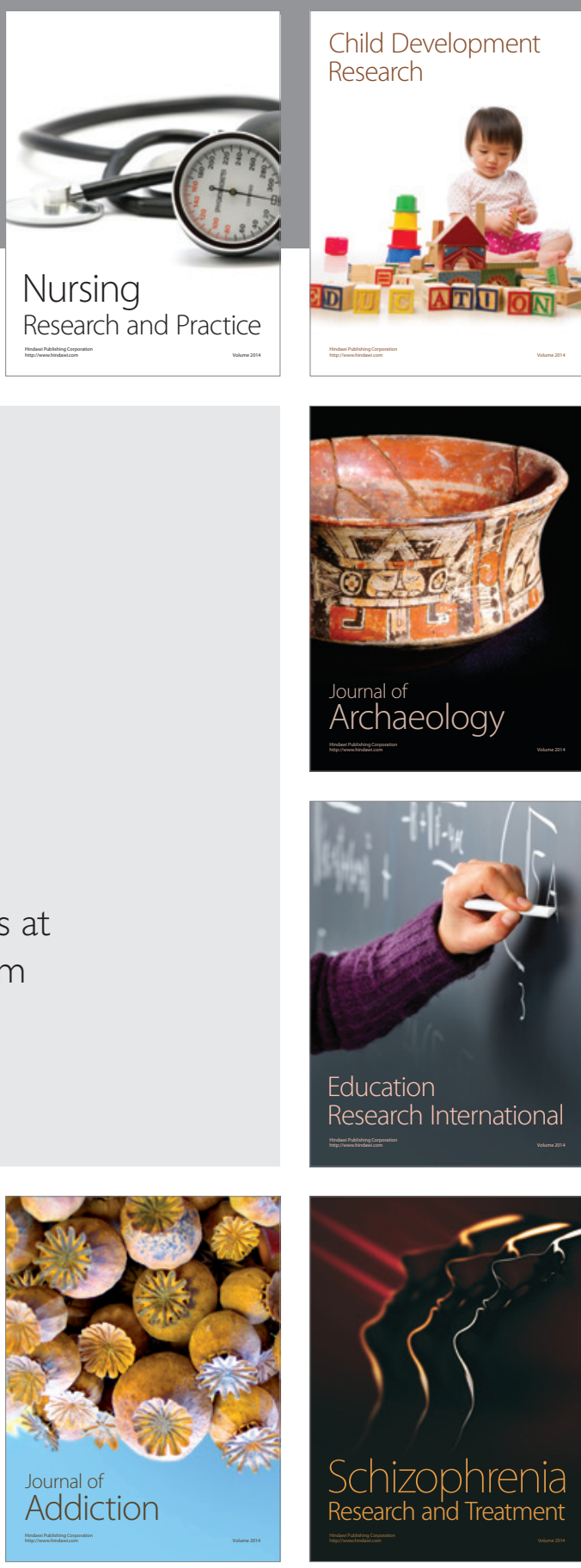

(D)
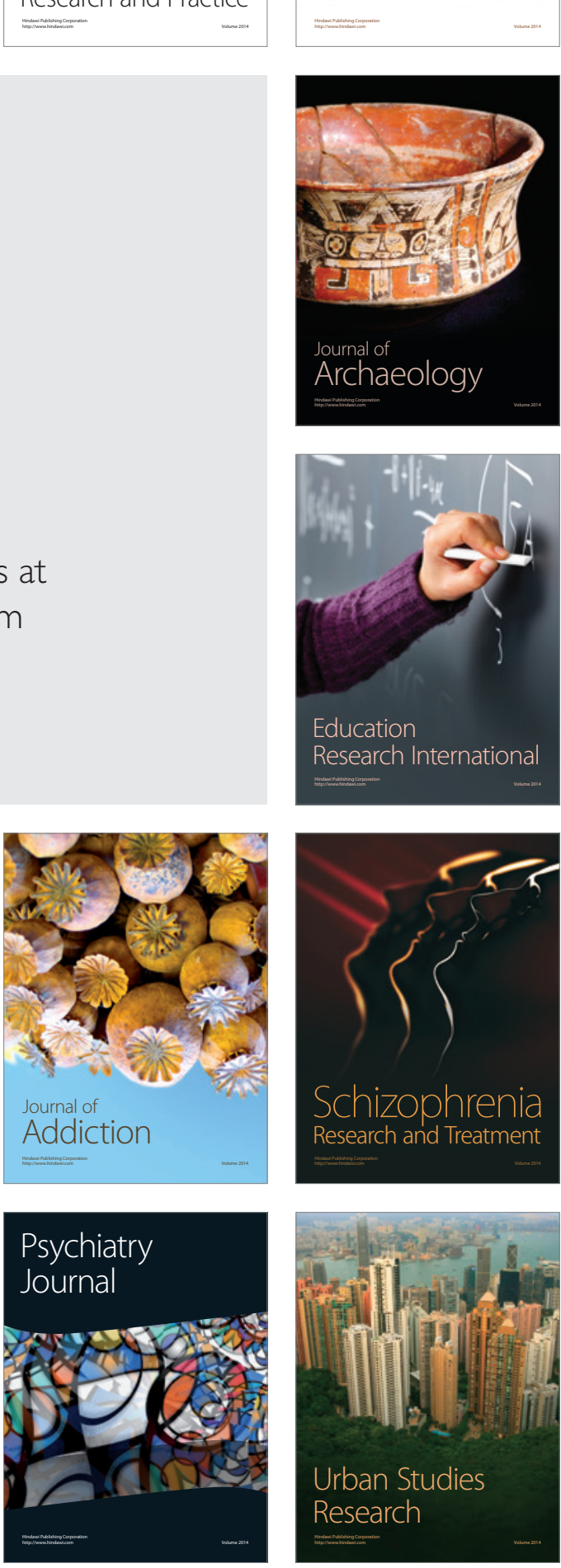